\title{
ANALISIS IMPLEMENTASI KEBIJAKAN PENCEGAHAN DAN PENANGGULANGAN HIV/AIDS DI PUSKESMAS HELVETIA KOTA MEDAN
}

\author{
Muchti Yuda Pratama, Fitriani Pramita Gurning \\ Program Studi DIII Keperawatan, Akper Kesdam I/Bukit Barisan Medan \\ E-mail : yudamuchti@yahoo.co.id \\ Fakultas Kesehatan Masyarakat, Universitas Islam Negeri Sumatera Utara \\ E-mail : fitrianigurning@uinsu.ac.id
}

\begin{abstract}
HIV/AIDS is a disease that continues to grow and become a global problem that swept the world. According to WHO (World Health Organization) data in 2017, the discovery of cases of HIV (Human Immunodeficiency Virus) in the world reached 36.9 million people living with HIV, estimated at $0.8 \%$ of people aged 15-49 years worldwide living with HIV. The purpose of this study was to determine the implementation of HIV/AIDS prevention and control policies in Helvetia Health Center, Medan. This research uses descriptive qualitative research. The informants chosen in the in-depth interview are the holders of HIV/AIDS prevention and control policy programs at the Helvetia Health Center. The number of respondents who filled out the questionnaire was 30 randomly drawn. Triangulation was carried out to check the validity of the data obtained from the results of interviews with informants and the results of filling out the questionnaire by the community in the Helvetia Puskesmas work area. Based on the results of research and discussion on the implementation of HIV/AIDS prevention and control policies conducted by the Helvetia Health Center using the theory of George C. Edward III, it is known that the communication between the implementers of the HIV / AIDS policy program at Helvetia Health Center with the target groups has been going well, the resources the HIV / AIDS program at Helvetia Health Center as a whole is good enough, the disposition or attitude of implementing tendencies already looks very good and the bureaucratic structure factor that can be seen from the indicators is also known that it has been going well.
\end{abstract}

Keywords : Implementation, Policy, HIV/AIDS

\begin{abstract}
Abstrak
Penyakit HIV/AIDS merupakan suatu penyakit yang terus berkembang dan menjadi masalah global yang melandadunia. Menurut data WHO (World Health Organization) tahun 2017, penemuan kasus HIV (Human Immunodeficiency Virus) di dunia mencapai 36,9 juta orang hidup dengan HIV, diperkirakan sebanyak 0,8\% orang berusia 15-49 tahun di seluruh dunia hidup dengan HIV. Tujuan penelitian ini untuk mengetahui pengimplementasian kebijakan pencegahan dan penanggulangan HIV/AIDS di Puskesmas Helvetia Medan. Penelitian ini menggunakan jenis penelitian kualitatif yang bersifat deskriptif. Informan yang dipilih dalam wawancara mendalaman adalah pemegang program kebijakan pencegahan dan pengendalian HIV/AIDS di Puskesmas Helvetia. Jumlah responden yang mengisi kuesioner sebanyak 30 yang diambil secara acak. Triangulasi dilakukan untuk memeriksa keabsahan data yang diperoleh dari hasil wawancara terhadap informan dan hasil pengisian kuesioner oleh masyarakat diwilayah kerja Puskesmas Helvetia. Berdasarkan hasil penelitian dan pembahasan mengenai implementasi kebijakan pencegahan dan pengendalian HIV/AIDS yang dilakukan oleh Puskemas Helvetia yang menggunakan teori George C. Edward III, diketahui bahwa komunikas iantara pelaksana program kebijakan HIV/AIDS di Puskesmas Helvetia dengan kelompok sasaran telah berjalan dengan baik, sumberdaya pada program HIV/AIDS di Puskesmas Helvetia secara keseluruhan sudah cukup baik, disposisi atau sikap kecenderungan pelaksana sudah terlihat sangat baik dan pada faktor struktur birokrasi yang dapat dilihat dari indikator-indikator juga diketahui bahwasannya telah berjalan dengan baik.
\end{abstract}

Kata Kunci : Implementasi, Kebijakan, HIV/AIDS 


\section{PENDAHULUAN}

Penyakit HIV/AIDS merupakan suatu penyakit yang terus berkembang dan menjadi masalah global yang melanda dunia. Menurut data WHO (World Health Organization) tahun 2017, penemuan kasus HIV (Human Immunodeficiency Virus) di dunia mencapai 36,9 juta orang hidup dengan HIV, diperkirakan sebanyak $0,8 \%$ orang berusia 15-49 tahun di seluruh dunia hidup dengan HIV. (WHO, 2017).

Berdasarkan dari pusat data dan informasi Kementerian Kesehatan RI statistik kasus HIV yang dilaporkan dari tahun 20062017 mengalami peningkatan, yaitu pada tahun 2006 kasus HIV sebesar 7.105 kasus, kemudian meningkat menjadi 48.300 kasus pada tahun 2017. Sedangkan AIDS juga meningkat dari tahun 2006 sebanyak 3.716 kasus, meningkat menjadi 9.280 kasus pada tahun 2017. Proporsi faktor risiko penderita HIV/AIDS melalui sero discordant (salah satu pasangan memiliki HIV, sementara yang lain tidak) merupakan cara penularan dengan persentase tertinggi yaitu sebesar $84,91 \%$, diikuti oleh melalui pelanggan pekerja seks dengan persentase sebesar $9,36 \%$, dan LSL (Lelaki seks lelaki) sebesar 6,94\%. Pada tahun 2017, jumah infeksi HIV tertinggi menurut kelompok umur yaitu pada umur 2549 tahun sebanyak 28.602. (Kemenkes RI, 2017)

Berdasarkan profil kesehatan kota medan jumlah kasus HIV dari kelompok umur kurang empat tahun sebanyak 2 orang, 5-14 tahun sebanyak 3 orang, 15-19 tahun sebanyak 9 orang, 20-24 tahun sebanyak 82 tahun, 25-49 tahun sebanyak 339 orang dan yang berumur 50 tahunan sebanyak 18 orang. Sedangkan penderita AIDS yang ditemukan berada pada umur 15-19 tahun sebanyak 2 orang, 20-24 tahun sebanyak 26 orang, 25-49 tahun sebanyak 133 orang dan yang berumur 50 tahun sebanyak 3 orang. Total dari keseluruhan penderita HIV dalah sebanyak 453 orang, sedangkan AIDS berjumlah 164 orang. (Dinkes Medan, 2016)

Berdasarkan Peraturan Daerah Kota Medan Nomor 1 Tahun 2012 Tentang Pencegahan dan Penanggulangan HIV dan
AIDS menjelaskan bahwa program pengurangan dampak buruk HIV/AIDS adalah kegiatan untuk memutuskan mata rantai penularan HIV dan AIDS yang terdiri dari 12 komponen yaitu: pendidikan sebaya, pelayanan kesehatan dasar, perawatan dan pengobatan HIV dan AIDS, subsititusional oral, terapi NAPZA, komunikasi informasi edukasi, penjankauan,VCT, konseling, pencegahan infeksi, pertukaran jarum suntik, dan pemusnahan jarum suntik bekas pakai. Berdasarkan profil puskesmas Helvetia bahwa jumlah kasus HIV AIDS mulai Januari 2018 hingga Juni 2019 di Puskemas Helvetia adalah 156 orang.

\section{METODE PENELITIAN}

Jenis penelitian ini menggunakan penelitian kualitatif yang bersifat deskriptif. Penelitian ini dilakukan di Puskesmas Helvetia yang beralamat di jalan Matahari Raya No. 47, Helvetia Tengah kec. Medan Helvetia, Kota Medan, Sumatera Utara. Penelitian dilakukan pada bulan Juni 2019. Jumlah repponden sebanyak 30 orang yang merupakan masyarakat diwilayah Helvetia tersebut.

\section{HASIL PENELITIAN}

Hasil penelitian Fasilitas kesehatan yang ada di Kecamatan Medan Helvetia dapat dikatakan masih sedikit dan belum merata di setiap kelurahannya. Namun demikian tenaga medis yang terdapat di Kecamatan Medan Helvetia ini sudah cukup tersebar di setiap kelurahan dimana pendistribusiannya disesuaikan dengan kebutuhan tiap-tiap kelurahan. Penyediaan listrik dari PLN dan penyediaan listrik dan penyediaan air dari PAM sudah lebih baik dari tahun sebelumya.

Kebijakan HIV/AIDS di Puskesmas Helvetia telah ada sejak tahun 2012 hal ini sesuai dengan mulai berlakunya Peraturan Daerah Kota Medan Nomor 1 Tahun 2012 tentang Pencegahan dan Penanggulangan HIV dan AIDS. Dalam implementasinya, kebijakan ini tidak menghadapi kendala apapun sebab telah ada SOP, SK pemegang program dan ada timmya lima orang yang 
terdiri dari perawat, admin, laboratorium, farmasi dan konseling. Tujuan dari kebijakan ini menurut pemegang program, jelas untuk menurunkan angka kasus dan supaya masyarakat-masyarakat yang mempunyai resiko tinggi sadar dan mau datang memeriksakan diri mereka ke Puskesmas Helvetia.

Upaya pencegahan dan penanggulanggan HIV AIDS yang telah diakukan oleh Puskesmas Helvetia yakni membagi kondom kepada pasien yang datang berobat, kemudian sering turun ke masyarakat seperti tempat spa dan panti pijat lalu memberikan kondom juga ke tempattempat itu dan melakukan penyuluhan atau memberi edukasi ke sekolah-sekolah seperti SMP dan SMA yang ada di Helvetia setiap bulan atau tiga bulan sekali. Dalam pelaksanaan program kebijakan HIV AIDS ini, Puskesmas Helvetia juga telah berkoordinasi dengan komisi penanggulangan HIV AIDS atau LSM seperti Yayasan Galateya, yayasan Meganplus, PKBI, P3M.

Terkait biaya khusus atau tambahan untuk pencegahan dan pengobatan HIV AIDS di Puskesmas Helvetia ini tidak ada yang dibebankan ke masyarakat. Pasien HIV AIDS yang mengambil obat tidak dikenakan biaya atau gratis. Sementara itu, mengenai sarana prasarana penunjang kebijakan ini, alat-alatanya sudah tersedia khusus seperti laptop, kulkas, komputer sendiri serta alatalat pemeriksaan yang semuanya diberikan oleh Dinas Kesehatan.

Tabel 1. Jumlah kunjungan konseling HIV AIDS Menurut Jenis kelamin mulai Januari 2018 hingga Juni 2019 Di Puskemas Helvetia

\begin{tabular}{clcc}
\hline \multirow{2}{*}{ No } & \multicolumn{1}{c}{ Bulan } & \multicolumn{2}{c}{ Jenis Kelamin } \\
\cline { 3 - 4 } & & $\begin{array}{c}\text { Laki- } \\
\text { Laki }\end{array}$ & $\begin{array}{c}\text { Perem- } \\
\text { puan }\end{array}$ \\
\hline 1. & Januari 2018 & 3 & 0 \\
2. & Februari 2018 & 3 & 1 \\
3. & Maret 2018 & 4 & 0 \\
4. & April 2018 & 6 & 1 \\
5. & Mei 2018 & 8 & 1 \\
6. & Juni 2018 & 7 & 1 \\
7. & Juli 2018 & 5 & 0 \\
\hline
\end{tabular}

\begin{tabular}{clcl}
\hline 8. & Agustus 2018 & 21 & 0 \\
9. & September 2018 & 7 & 1 \\
10. & Oktober 2018 & 4 & 1 \\
11. & November 2018 & 11 & 1 \\
12. & Desember 2018 & 6 & 1 \\
13. & Januari 2019 & 19 & 1 \\
14. & Februari 2019 & 7 & 0 \\
15. & Maret 2019 & 11 & 0 \\
16. & April 2019 & 10 & 0 \\
17. & Mei 2019 & 11 & 0 \\
18. & Juni 2019 & 4 & 0 \\
\hline & Jumlah & 147 & 9 \\
\hline & Total & 156 & \\
\hline
\end{tabular}

Tabel 2. Data rekapitulasi kunjungan tes HIV positif pada kelompok resiko tinggi tertular HIV AIDS diklinik IMS dan VCT Di Puskemas Medan Helvetia

\begin{tabular}{llc}
\hline No. & $\begin{array}{c}\text { Kumlah } \\
\text { Telompok Risiko Tinggi } \\
\text { Tertular HIV AIDS }\end{array}$ & $\begin{array}{c}\text { yang } \\
\text { HIV } \\
\text { AIDS } \\
\text { Positif }\end{array}$ \\
\hline 1. & Wanita pekerja Seks (WPS) & 3 \\
2. & Lelaki Seks Lelaki ( LSL) & 123 \\
3. & Pasangan Resiko Tinggi & 15 \\
4. & Pasangan pekerja seks & 2 \\
5. & Lain-lain & 8 \\
\hline \multicolumn{2}{c}{ Jumlah } & 151 \\
\hline
\end{tabular}

Dari 30 responden yang mengisi kuesioner. Diketahui bahwa, lebih banyak masyarakat yang tidak mengetahui ada kebijakan HIV dan AIDS di Puskesmas Helvetia yaitu sebanyak 197 orang. Sedangkan yang mengetahui ada kebijakan tersebut sebanyak 103 orang.

\section{PEMBAHASAN \\ Indikator Keberhasilan Implementasi Kebijakan}

Berdasarkan hasil dari wawancara yang telah dilakukan dengan petugas pemegang program HIV/AIDS di Puskesmas Helvetia serta dikaitkan dengan hasil kuesioner yang dijawab oleh 30 responden, maka beberapa indikator terkait keberhasilan implementasi kebijakan yaitu :

\section{Komunikasi}

Komunikasi antara pelaksana program kebijakan HIV/AIDS di Puskesmas 
Helvetia dengan kelompok sasaran telah berjalan dengan baik. Hal ini dilihat dari ketiga indikator transmisi, kejelasan dan konsisten. Pada indikator transmisi komunikasi sudah berjalan baik karena informasi yang disampaikan langsung diberikan kepada sasaran kebijakan yaitu kelompok-kelompok resiko tinggi, komunitas-komunitas ODHA, pelajar dan masyarakat. Indikator kejelasan komunikasi sudah cukup baik karena program HIV/AIDS dilakukan dengan cara sosialisasi langsung.

Untuk sasaran pelajar, hal ini sudah sesuai sebagaimana dijelaskan oleh petugas pemegang program yang mengatakan " $a d a$ kita melakukan penyuluhan setiap bulan atau 3 bulan sekali ke sekolah-sekolah seperti SMP dan SMA yang ada di Helvetia ini". Beliau mengatakan bahwa untuk ke sekolah dilakukan penyuluhan setiap bulan ataupun 3 bulan sekali. Hal ini juga sesuai dengan jawaban responden yang mana sebanyak 15 orang (50\%) mengaku bahwa dilakukan adanya promosi tentang HIV/AIDS yang dilakukan oleh Puskesmas Helvetia.

Untuk kelompok-kelompok resiko tinggi, komunitas-komunitas ODHA, sudah sesuai dengan penjelasan pemegang program yang mengatakan bahwa "pertiga bulan sekali kita kumpulkan pasien HIV kita buka kelas ODHA jadi setiap 3 bulan sekali baik pasien baru maupun pasien lama kita kumpulkan sharing kekmana mereka sudah percaya diri atau belum kekmana yang sudah makan obat yang baru makan obat atu pasien yang pasien belum positif itu ada juga pertemua kita misal kita bekerja samaa dengan galateya untu pasien yang beresiko kita buat pertemuan pertiga bulan sekali untuk pasien yang beresiko ini minggu kemarin kita adain pertemuan untuk LSL kita penjangkauan yang belum positif kita periksa". Beliau mengatakan bahwa untuk 3 bulan sekali biasanya pasien HIV dikumpulkan untuk diberikan penyuluhan maupun sharing agar mereka lebih percaya diri serta pemberian obat kepada pasien HIV/AIDS. Tetapi, hal ini tidak sejalan dengan jawaban responden yang mana sebanyak 11 orang $(36,7 \%)$ mengaku tidak tahu adanya pemberian edukasi terhadap pasien HIV/AIDS maupun kelompok berisiko dikarenakan responden merupakan masyarakat umum.

\section{Sumber Daya}

Sumber daya pada program HIV/AIDS di Puskesmas Helvetia secara keseluruhan sudah cukup baik. Sebagaimana petugas pemegang program mengatakan bahwa "ada timmya 5 orang ada perawat, Adminnya, laboratorium, farmasinya, dan ada konselingnya". Hal ini di sampaikan oleh pemegang program bahwa selama ini tidak ada hambatan serta petugas dalam satu tim ada 5 orang yang mana terdiri dari perawat ,admin, laboratorium, farmasi, dan ada konseling.

Sedangkan faktor sarana dan prasarana serta finansial sudah terpenuhi dengan baik. Pemegang program mengatakan bahwa "sarana prasarana alat alatanya memang sudah khusus kita ada laptop, kulkas komputer sendiri di kasih dari dinas alat-alat pemeriksaan itu di kasih semua". Hal ini berarti bahwa dari pihak dinas kesehatan telah memberikan dan menyediakan secara lengkap sarana dan prasarana yang mendukung guna keberhasilan implementasi kebijakan HIV/AIDS di Puskesmas Helvetia. Tetapi, menurut jawaban responden sebanyak 21 orang $(70 \%)$ mengaku tidak tahu akan adanya sarana dan prasarana yang mendukung program HIV/AIDS. Hal ini dikarenakan responden merupakan masyarakat umum.

Untuk bagian finansial juga sudah tercukupi, sebagaimana penjelasan pemegang program yang mengatakan bahwa "gratis, tidak ada, bpjs gratis itu dari program mereka punya bpjs mau gak punya bpjs tetap gratis sетиа mengambil obat gratis tapi kalau perika lab misal kaya sakit gula hepatitus itu baru bayar kalau gak ada bpjs nya tapi kita gak bayar disini kita bayar di lab nya karena kita disini semua gratis". Hal ini dikarenakan puskesmas tidak memungut biaya tambahan, baik bagi peserta BPJS maupun yang tidak punya BPJS. Hal ini juga 
sejalan dengan jawaban dari responden sebanyak 25 orang $(83,3 \%$ ) yang mengatakan bahwa tidak ada pemungutan biaya apapun terkait dengan program HIV/AIDS di Puskesmas Helvetia.

\section{Disposisi atau Sikap}

Disposisi atau Sikap kecenderungan pelaksana sudah terlihat sangat baik. Hal ini dikarenakan adanya dukungan dari berbagai pihak yang mendukung sepenuhnya program HIV/AIDS untuk mencapai Indonesia bebas penyakit menular. Para pelaksana juga telah memberikan pelayanan yang baik, sopan dan ramah, menjadi salah satu bukti bahwa tenaga pelaksana benar-benar memiliki kemauan dan kepatuhan dalam melaksanakan program penanggulangan HIV/AIDS di Puskesmas Helvetia.

\section{Faktor Struktur Birokrasi}

Pada faktor struktur birokrasi dapat dilihat dari indikator-indikator, yaitu: . pertama, indikator SOP pada Puskesmas Helvetia selaku pelaksana program sudah memiliki SOP khusus. Dalam memberikan layanan kepada masyarakat diserahkan kepada masing-masing stakeholder. Kedua, indikator fragmentasi telah berjalan baik karena telah sesuai dengan peran dan tugas serta koordinasi antar pihak pelaksana dalam penyuluhan. Hal ini sebagaimana yang dijelaskan oleh petugas pemegang program yang mengatakan bahwa "kebijakan HIV AIDS di puskesmas ini ada, ada SOP nya ada SK pemegang program”.

\section{KESIMPULAN}

Komunikasi antara pelaksana program kebijakan HIV/AIDS di Puskesmas Helvetia dengan kelompok sasaran telah berjalan dengan baik. Hal ini dilihat dari ketiga indikator transmisi, kejelasan dan konsisten. Pada indikator transmisi komunikasi sudah berjalan baik karena informasi yang disampaikan langsung diberikan kepada sasaran kebijakan yaitu kelompok-kelompok resiko tinggi, komunitas-komunitas ODHA, pelajar dan masyarakat. Indikator kejelasan komunikasi sudah cukup baik karena program HIV/AIDS dilakukan dengan cara sosialisasi langsung. Sumber daya pada program HIV/AIDS di Puskesmas Helvetia secara keseluruhan sudah cukup baik. Hal ini di sampaikan oleh pemegang program bahwa selama ini tidak ada hambatan serta petugas dalam satu tim ada 5 orang yang mana terdiri dari perawat ,admin, laboratorium, farmasi, dan ada konseling. Sarana dan prasarana khusus untuk HIV/AIDS juga lengkap sudah diseaiakan. Tetapi, menurut jawaban responden sebanyak 21 orang (70\%) mengaku tidak tahu akan adanya sarana dan prasarana yang mendukung program HIV/AIDS. Hal ini dikarenakan responden merupakan masyarakat umum. Untuk bagian finansial juga sudah tercukupi.

\section{SARAN}

Untuk meningkatkan upaya program penanggulangan HIV/AIDS di Puskesmas Helvetia perlu adanya penyuluhan kepada masyarakat umum di sekitar wilayah kerja Puskesmas. Hal ini dikarekan masih banyak masyarakat umum yang mengaku belum mengetahui adanya kebijakan HIV/AIDS di Puskesmas Helvetia.

\section{REFERENSI}

Anggara, S. (2012). Ilmu Administrasi Negara Kajian Konsep, Teori, Dan Fakta Dalam Upaya Menciptakan Good Governance . Bandung: Pustaka Setia.

Departemen Kesehatan Republik Indonesia. (2003). "Penanggulangan HIV/AIDS di Indonesia" (Online). http://data.unaids.org (Diakses 21 Mei 2019).

Departemen Kesehatan Republik Indonesia. (2006). "Pedoman Pelayanan Kefarmasian Untuk Orang dengan HIV/AIDS (ODHA)". Direktorat Bina Farmasi Komunitas dan Klinik Ditjen Bina Kefarmasian dan Alat Kesehatan Departemen Kesehatan RI (Online). http://binfar.depkes.go.id (Diakses 23 April 2019). 
Dinkes Kota Medan. (2016). Profil Kesehatan Kota Medan.

Gunawan, R, Pratama, M.Y, Sulaiman, Anggriani, Gurning, F.P. (2018). Increasing of HIV/AIDS Prevention and Drugs Through Whatsapp Based Training and Assistance in Adolescents in Batang Kuis Deli Serdang District. International Journal of Scientific \& Engineering Research. Volume 9, Issue 9, September 2018. ISSN 2229-5518. Tanggal akses 9 Oktober 2019.

Gurning, F.P, Daulay, A.J. (2017). Pembinaan Puskesmas Terhadap Pelaksanaan Program Usaha Kesehatan Sekolah di Wilayah Puskesmas Padang Matinggi Kota Padangsidimpuan. JUMANTIK (Jurnal Ilmiah Penelitian Kesehatan). Volume 3, No.1, 2017. Tanggal akses 10 November 2019.

Hartono, A. (2009). "Faktor Risiko Kejadian Penyakit Menular Seksual (PMS) pada Komunitas Gay Mitra Strategis Perkumpulan Keluarga Berencana Indonesia (PKBI) Yogyakarta." Skripsi Sarjana Program Studi Kesehatan Masyarakat Fakultas Ilmu Kesehatan Universitas Muhammadiyah, Surakarta (Online). http://etd.eprints.ums.ac.id (Diakses Maret 2019).

Kusuma, P.W. (2011). "Definisi Perilaku Seksual" (Online). http://pwkorganization. blogspot.com (Diakses 14 Maret 2019).

Mandal, B.K, et al., eds. (2006). "Lecture Notes: Penyakit Infeksi" edisi keenam. Jakarta: Erlangga,

Notoatmodjo, S. (2005). "Metodologi Penelitian Kesehatan". Cet. 3. Jakarta: PT. Rineka Cipta.

Nugroho, K. Priyo dan Sugih, H. (2009). "Perilaku Seksual dan Struktur Sosial: Studi tentang Epidemic HIV dan AIDS di Indonesia." (Online). Jurnal Indonesian Society for Social Transformation

(INSIST) Yogyakarta (Diakses Agustus 2019).
Prianti, Martina dan Nurul Fitriani. 2011. "Usia Produktif Dorong Pertumbuhan Ekonomi" (Online). http://www.indonesiafinancetoday.co m. (Diakses 23 April 2019).

Raharjo, T. (2009). "Dorongan Seksual dan Kecenderungan Perilaku Homoseksual pada Santri Remaja di Pesantren" (Online). Jurnal Muria Universitas Muria Kudus (Diakses Agustus 2019).

Suryani, Mega, D, et al., eds. (2009). "Makalah Diagnostik Klinik HIVAIDS" (Online). Departemen Farmasi Fakultas Matematika \& Ilmu Pengetahuan Alam Universitas Indonesia. http://exuico.multiply.com (Diakses 23 April 2019). 